\title{
Reference values for lysosomal enzymes activities using dried blood spots samples - a Brazilian experience
}

\author{
Karen B Müller ${ }^{1}$, Mayra DB Rodrigues ${ }^{1}$, Vanessa G Pereira ${ }^{1}$, Ana M Martins', Vânia D'Almeida ${ }^{1,2^{*}}$
}

\begin{abstract}
Background: Lysosomal storage diseases (LSD) are inherited disorders caused by deficiency of lysosomal enzymes in which early diagnosis is essential to provide timely treatment. This study reports interval values for the activity of lysosomal enzymes that are deficient in Mucopolysaccharidosis type I, Fabry, Gaucher and Pompe disease, using dried blood spots on filter paper (DBS) samples in a Brazilian population.

Results: Reference activity values were obtained from healthy volunteers samples for alpha-galactosidase A (4.57 \pm $1.37 \mathrm{umol} / \mathrm{L} / \mathrm{h}$ ), beta-glucosidase (3.06 $\pm 0.99 \mathrm{umol} / \mathrm{L} / \mathrm{h}$ ), alpha-glucosidase (ratio: $13.19 \pm 4.26$; \% inhibition: $70.66 \pm$ 7.60), alpha-iduronidase (3.45 $\pm 1.21 \mathrm{umol} / \mathrm{L} / \mathrm{h})$ and beta-galactosidase (14.09 $\pm 4.36 \mathrm{umol} / \mathrm{L} / \mathrm{h})$.

Conclusion: Reference values of five lysosomal enzymes were determined for a Brazilian population sample. However, as our results differ from other laboratories, it highlights the importance of establishing specific reference values for each center.
\end{abstract}

\section{Introduction}

Lysosomal storage diseases (LSD) comprise a group of more than 40 inherited disorders caused by deficiency of specific lysosomal hydrolases, which results in the accumulation of different macromolecules in the lysosome, leading to cell dysfunction and progressive clinical manifestations [1,2].

Most LSD are inherited in an autosomal recessive manner, with the exception of Hunter, Fabry and Danon diseases that are X-linked. As a group, LSD have an incidence of about 1 per 7700 live births [3].

For some LSD as Fabry, Gaucher and Pompe diseases (FD, GD and PD respectively) and Mucopolysaccharidosis type I (MPS I), enzyme replacement therapy has been widely used as a treatment option, improving the quality of life and prognosis of these patients. Since those diseases are all progressive, early diagnosis is an essential tool for a successful treatment [2].

Biochemical diagnosis of LSD is performed by determination of enzymatic activities in different biological

\footnotetext{
* Correspondence: vaniadalmeida@uol.com.br

'Department of Pediatrics - Universidade Federal de São Paulo (UNIFESP),

São Paulo, Brazil

Full list of author information is available at the end of the article
}

fluids (as plasma, leukocytes, fibroblasts and most recently dried blood spots on filter paper (DBS)), using fluorimetry, immunocapture and mass spectrometry assays [4-8]. One of the advantages for the use of DBS in the diagnosis of LSD is that these samples may be transported safely through long distances, including mailing in regular envelopes, because enzyme activities remain stable for months at room temperature [8]. In addition, the preparation of a DBS sample requires only a small amount of blood [9]. These advantages are especially important in large countries like Brazil, in which there are few reference laboratories to perform these assays.

Several studies have demonstrated the feasibility of using DBS to diagnose LSD [9-11], but it is important to establish specific reference values to each center, since enzyme activity may vary due to specific characteristics of each population and mainly because different assay conditions. Therefore, the aim of this study was to establish a reference interval value for the activities of the following lysosomal enzymes in a Brazilian population sample: alpha-galactosidase A ( $\alpha$ gal A), beta-glucosidase $(\beta$ glu), acid alpha-glucosidase ( $\alpha \mathrm{glu})$, alpha-iduronidase ( $\alpha$ idua), which are used for the diagnosis of FD, GD, PD
C Biomed Central

C 2010 Müller et al; licensee BioMed Central Ltd. This is an Open Access article distributed under the terms of the Creative Commons Attribution License (http://creativecommons.org/licenses/by/2.0), which permits unrestricted use, distribution, and reproduction in any medium, provided the original work is properly cited. 
and MPS I respectively, and also beta-galactosidase ( $\beta$ gal), used as a quality control tool.

\section{Methods}

This study was performed at Laboratório de Erros Inatos do Metabolismo (LEIM) from Universidade Federal de São Paulo (UNIFESP). Research protocols and consent forms as well as the overall investigation were ethically and scientifically approved by the Medical Research and Ethical Committee of UNIFESP (0384/05).

Brazilian healthy volunteers (HV) between the ages of 18 and 80 and without a known genetic or chronic disease were selected for our study. Samples were collected from 164 individuals ( $42 \%$ male and $58 \%$ female). Blood specimens were collected by venipuncture into heparin tubes and spotted on Whatman 903 filter paper. Samples collected at UNIFESP were dried at room temperature for at least 4 hours and stored at the same day at $4{ }^{\circ} \mathrm{C}$ in sealed plastic bags with desiccant (to prevent hydration) until analysis. Those collected at other locations were prepared and dried in the same conditions (detailed instructions were sent to those centers), sealed in plastic bags and sent to the laboratory in a maximal interval of 5 days, where they were stored at $4^{\circ} \mathrm{C}$. Only high quality DBS, evaluated by their macroscopic aspect (absence of jagged edges and clots, and adequate amount of blood on the spot) and biochemically by $\beta$ gal activity $[9,12]$ were used in this work.

DBS enzyme activity assays were adapted from the methods described by Chamoles and coworkers [8,13-17]. $\alpha$ gal A, $\alpha$ glu, $\alpha$ idua, $\beta$ gal were assayed on microplates and $\beta$ glu was assayed on microtubes. For microplate assays, $1.5 \mathrm{~mm}$ diameter (1/16 inch) disks were punched from each DBS and placed into separate wells in a 96-well blank plate. For microtube assay, $3.0 \mathrm{~mm}$ diameter (1/8 inch) disks were punched from DBS and placed into separate $2.0 \mathrm{~mL}$ microtubes. DBS removal from the wells/tubes during the analysis was not necessary.

Reaction buffers, fluorogenic substrates, additional reagents and incubation time used for each DBS assay are described in Table 1. Assays were performed in duplicate and with one blank per sample, which was prepared by adding all reagents except the substrate. The microplate/microtube reactions and substrate solution were incubated separately at $37^{\circ} \mathrm{C}$ in an orbital shaker. After incubation, substrate solution was added to blanks and the stop buffer was added to all wells/ tubes. The enzyme product 4-methylumbelliferone was detected (excitation $365 \mathrm{~nm}$; emission $450 \mathrm{~nm}$ ) in a fluorometer SpectraMax M2 (Molecular Devices). Fluorescence readings were corrected by blanks, and results were compared to a 4-methylumbelliferone calibration curve. Enzymatic activities were expressed as micromoles of hydrolyzed substrate per liter of blood per hour $(\mu \mathrm{mol} / \mathrm{L}$ blood$/ \mathrm{h})$, with the exception of $\alpha$ glu, which was expressed as the ratio of neutral and lysosomal isoforms (NaG/AaGIA) and \% inhibition of total acid fraction $[9,17]$.

DBS samples from two healthy individuals have been used as internal controls in every reaction as well as a DBS from a confirmed patient. Within-assay coefficients of variation (CVs) were calculated from an internal control sample analyzed in all assays.

Data are expressed as mean \pm standard deviation (SD). The parametric Student's $t$ test was performed to compare mean activity values from both genders in HV group. The level of significance for statistical analysis was set at 0.05 . All analyses were performed using the software MINITAB ${ }^{\circ}$ 15.1.1.0.

\section{Results}

$\beta$ gal activity was analyzed in HV to establish its reference interval for our population and the range was 7.85 and $22.15 \mu \mathrm{mol} / \mathrm{L}$ blood/h (percentile 5 and $95 \mathrm{respec}-$ tively). $\beta$ gal was used as control enzyme, and DBS samples with $\beta$ gal activity lower or higher than the normal range have not been included in this study, as they were considered inappropriate. The mean, standard deviation and interval values of the different enzymatic activities are described in Table 2. A significant difference between genders was observed for $\beta$ glu (male: 2.82; female: 3.23; $\mathrm{p}=0.0053$ ) and $\beta$ gal activities (male: 12.61 ; female: $15.17 ; \mathrm{p}=0.0001$ respectively), which could be due to the higher number of female subjects in the HV group (69 males versus 95 females).

Our results differ from enzymatic activity values previously described by Chamoles and coworkers, especially for aidua activity (our mean activity: 3.45; Chamoles et al:: 5.50) [8,13-17]. Regarding the study from Civallero and coworkers, in which several lysosomal enzymes activities were evaluated in another Brazilian sample, a difference in mean values was also observed, mainly for $\beta$ glu activity (our mean value: 3.09; Civallero et al.: 4.92) [7]. This difference may be explained by sample size issues, differences in equipment, chemicals or water or even by ethnic diversity, once the Brazilian population is known to be composed of a variety of ethnic backgrounds [18]. However, these differences highlight the importance of determining specific reference values for each laboratory or reference center.

Within-assay CVs of internal controls were around $10 \%$, interassay CVs did not exceed $20 \%$ and imprecision data are in accordance with other related studies $[8,15,19,20]$.

\section{Discussion}

Different biological materials have been used to diagnose LSD patients, but recently several studies have described the advantages of DBS $[9,19,20]$. These 
Table 1 Assay conditions for each enzyme activity assay

\begin{tabular}{|c|c|c|c|c|c|c|}
\hline ENZYME & $\begin{array}{l}\text { Punch } \\
\text { diameter }\end{array}$ & Reaction buffer & Fluorogenic substrate & Additional reagents & $\begin{array}{l}\text { Incubation } \\
\text { time }\end{array}$ & Stop buffer \\
\hline $\begin{array}{c}\text { alpha- } \\
\text { galactosidase A }\end{array}$ & $1.5 \mathrm{~mm}$ & $\begin{array}{c}30 \mu \mathrm{L} \text { citrate-phosphate } \\
0.3 \mathrm{M} \mathrm{pH} 5.0\end{array}$ & $\begin{array}{c}30+30^{*} \mu \mathrm{L} \\
4 \mathrm{MU} \text {-alpha-D- } \\
\text { galactopyranoside } 4.2 \\
\mathrm{mM}\end{array}$ & $\begin{array}{c}10 \mu \mathrm{L} \\
\mathrm{N} \text {-acetyl-galactosamine } \\
0.25 \mathrm{M}\end{array}$ & 20 hours & $\begin{array}{c}10 \% \\
\text { ethylenediamine } \\
1.32 \mathrm{M} \mathrm{pH} 11.3\end{array}$ \\
\hline alpha-iduronidase & $1.5 \mathrm{~mm}$ & $\begin{array}{c}10 \mu \mathrm{L} \\
\text { sodium formate } 0.2 \mathrm{M} \mathrm{pH} \\
2.8\end{array}$ & $\begin{array}{c}20+20^{*} \mu \mathrm{L} \\
4 \mathrm{MU} \text {-alpha-L- } \\
\text { idopyranoside } \\
2 \mathrm{mM}\end{array}$ & $\begin{array}{c}10 \mu \mathrm{L} \\
\text { D-saccharic acid } \\
\text { 1,4-lactone monohydrate } \\
3 \mathrm{mM}\end{array}$ & 20 hours & $\begin{array}{c}10 \% \\
\text { ethylenediamine } \\
1.32 \mathrm{M} \mathrm{pH} 11.3\end{array}$ \\
\hline beta-glucosidase & $3.0 \mathrm{~mm}$ & $\begin{array}{c}30 \mu \mathrm{L} \text { citrate-phosphate } \\
0.4 \mathrm{M} \mathrm{pH} 5.2\end{array}$ & $\begin{array}{c}50+50^{*} \mu \mathrm{L} \\
4 \mathrm{MU}-\text { beta-D- } \\
\text { glycopyranoside } 20 \mathrm{mM}\end{array}$ & $\begin{array}{c}40 \mu \mathrm{L} \\
\text { sodium taurodeoxicolate } \\
\text { hydrate } 0.75 \%\end{array}$ & 20 hours & $\begin{array}{c}10 \% \\
\text { ethylenediamine } \\
1.32 \mathrm{M} \mathrm{pH} 11.3 \\
\end{array}$ \\
\hline alpha-glucosidase & $1.5 \mathrm{~mm}$ & $\begin{array}{c}20 \mu \mathrm{L} \\
\text { sodium acetate } 0.4 \mathrm{M} \mathrm{pH} \\
4.0 \text { and } 6.5\end{array}$ & $\begin{array}{c}20+20^{*} \mu \mathrm{L} \\
4 \mathrm{MU} \text {-alpha-D- } \\
\text { glycopyranoside } 2.8 \mathrm{mM}\end{array}$ & $\begin{array}{c}40 \mu \mathrm{L} \\
\text { acarbose } 40 \mu \mathrm{M}\end{array}$ & 24 hours & $\begin{array}{c}10 \% \\
\text { ethylenediamine } \\
1.32 \mathrm{M} \mathrm{pH} 11.3\end{array}$ \\
\hline beta-galactosidase & $1.5 \mathrm{~mm}$ & $\begin{array}{c}20 \mu \mathrm{L} \text { citrate-phosphate } \\
0.1 \mathrm{M} \mathrm{pH} 4.4\end{array}$ & $\begin{array}{c}20+40^{*} \mu \mathrm{L} \\
4 \mathrm{MU}-\text { beta-D- } \\
\text { galactopyranoside } 0.8 \\
\mathrm{mM}\end{array}$ & $\begin{array}{l}20 \mu \mathrm{L} \text { sodium chloride } \\
0.9 \%\end{array}$ & 3 hours & $\begin{array}{c}10 \% \\
\text { ethylenediamine } \\
1.32 \mathrm{M} \mathrm{pH} 11.3\end{array}$ \\
\hline
\end{tabular}

* addition in blank wells after incubation.

MU: methylumbilliferyl.

samples can be easily and safely transported by regular mail, even at room temperature, without altering enzyme activity $[14,15]$. In addition, DBS minimizes biological hazards, since the blood is impregnated in the filter paper and only a small amount of blood is required to perform the assay. Moreover, these samples do not require special storage conditions and the assay on microplate is easier to perform and less expensive than other techniques $[8,9]$.

Although we did not evaluate newborns in this study, it is known that this group has a higher range of enzyme activity $[7,8]$. Therefore, it is important to emphasize that a specific range must be taken into account when analyzing newborn patients. In addition, it is important to obtain a reference interval value for this particular population if these assays would be included in newborn screening programs.

It is also extremely important to emphasize that in order to guarantee the quality of diagnosis, blood collection and DBS samples preparation must be done carefully, and the determination of a control enzyme, such as $\beta$ gal or hexosaminidase should be performed as a quality control tool $[9,12,14]$.

Although it has been demonstrated that these enzymes activities are maintained stable on DBS samples, we suggest that a sample from a healthy volunteer should be sent to the laboratory for analysis along with the samples of clinically suspected patients, which could point out any unexpected decrease of the enzymes activities during transportation $[8,9]$. Therefore, the establishment of reference values from healthy volunteers could be useful as an additional quality control tool for DBS assays.

We believe that the determination of enzyme activity using DBS samples is the best option for screening patients with LSD, especially in high risk groups. This alternative has several advantages that outweigh an initial evaluation of suspected subjects using DBS samples. However, as some of our results differ from other laboratories, it highlights the importance of establishing specific reference values for each reference center.

The establishment of reference values for lysosomal enzyme activities on DBS in a Brazilian population may

Table 2 Enzyme activities from HV DBS samples

\begin{tabular}{|c|c|c|c|c|c|c|}
\hline & $\alpha$-gal A & $\alpha$-idua & $\mathrm{NaG} / \mathrm{AaGIA}$ & $\%$ inhibition & $\beta$-glu & $\beta$-gal \\
\hline$n$ & 164 & 164 & 164 & 164 & 156 & 164 \\
\hline mean & 4.57 & 3.45 & 13.19 & 70.66 & 3.06 & 14.09 \\
\hline$S D$ & 1.37 & 1.21 & 4.26 & 7.60 & 0.99 & 4.36 \\
\hline interval & $1.44-10.67$ & $1.40-7.78$ & $5.03-28.58$ & $36.38-87.08$ & $1.51-7.23$ & $4.04-29.65$ \\
\hline
\end{tabular}

Data expressed as $\mu \mathrm{mol} / \mathrm{L}$ blood $/ \mathrm{h}$.

$\mathrm{n}=$ number of samples.

$\mathrm{SD}=$ standard deviation.

Interval = established as minimum to maximum.

$\%$ inhibition $=$ percent of other alpha-glucosidase isoforms inhibition. 
facilitate the use of this test as a tool for LSD diagnosis in our country, and even enable the implantation of a newborn screening program.

\section{Acknowledgements}

We would like to thank: students and technicians from LEIM, all individuals who agreed to participate and the physicians. We wish to express our gratefulness to FAPESP (K.B.M. scholarship), CAPES (V.G.P scholarship), CNPq (process $n^{\circ}$ \# 501248/2005-6), AFIP and IGEIM. V.D'A. is recipient of CNPq researcher fellowship.

\section{Author details}

'Department of Pediatrics - Universidade Federal de São Paulo (UNIFESP), São Paulo, Brazil. ${ }^{2}$ Department of Biosciences - Universidade Federal de São Paulo (UNIFESP), Santos, Brazil.

\section{Authors' contributions}

KBM, MDBR and VGP participated in the collection of samples, determination of enzyme activities, analysis and interpretation of data and drafting the manuscript. AMM helped with samples collection and the design of the study. VD participated in the design of the study, its coordination and critically revised the manuscript. All authors have read and approved the final manuscript version.

\section{Competing interests}

The authors declare that they have no competing interests.

Received: 6 August 2010 Accepted: 29 September 2010 Published: 29 September 2010

\section{References}

1. Scriver CRBAL, Sly WS, Valle D, Childs R, Kinzler KW: The Metabolic Basis of Inherited Disease New York: McGraw-Hill 2001.

2. Platt FM, Lachmann RH: Treating lysosomal storage disorders: current practice and future prospects. Biochim Biophys Acta 2009, 1793:737-745.

3. Meikle PJ, Hopwood JJ, Clague AE, Carey WF: Prevalence of lysosomal storage disorders. JAMA 1999, 281(3):249-254.

4. Omura K, Higami S, Tada K: alpha-L-iduronidase activity in leukocytes: diagnosis of homozygotes and heterozygotes of the Hurler syndrome. Eur J Pediatr 1976, 122:103-105.

5. Gelb MH, Turecek F, Scott CR, Chamoles NA: Direct multiplex assay of enzymes in dried blood spots by tandem mass spectrometry for the newborn screening of lysosomal storage disorders. J Inherit Metab Dis 2006, 29:397-404.

6. Fuller M, Lovejoy M, Brooks DA, Harkin ML, Hopwood JJ, Meikle PJ: Immunoquantification of alpha-galactosidase: evaluation for the diagnosis of Fabry disease. Clin Chem 2004, 50:1979-1985.

7. Civallero G, Michelin K, de Mari J, Viapiana M, Burin M, Coelho JC Giugliani R: Twelve different enzyme assays on dried-blood filter paper samples for detection of patients with selected inherited lysosomal storage diseases. Clin Chim Acta 2006, 372:98-102.

8. Chamoles NA, Blanco MB, Gaggioli D, Casentini C: Hurler-like phenotype: enzymatic diagnosis in dried blood spots on filter paper. Clin Chem 2001, 47:2098-2102.

9. Gasparotto N, Tomanin R, Frigo AC, Niizawa G, Pasquini E, Blanco M, Donati MA, Keutzer J, Zacchello F, Scarpa M: Rapid diagnostic testing procedures for lysosomal storage disorders: alpha-glucosidase and betagalactosidase assays on dried blood spots. Clin Chim Acta 2009, 402(12):38-41.

10. Kallwass H, Carr C, Gerrein J, Titlow M, Pomponio R, Bali D, Dai J, Kishnani P, Skrinar A, Corzo D, Keutzer J: Rapid diagnosis of late-onset Pompe disease by fluorometric assay of alpha-glucosidase activities in dried blood spots. Mol Genet Metab 2007, 90:449-452.

11. Li Y, Scott CR, Chamoles NA, Ghavami A, Pinto BM, Turecek F, Gelb MH: Direct multiplex assay of lysosomal enzymes in dried blood spots for newborn screening. Clin Chem 2004, 50:1785-1796.

12. Lukacs Z, Keil A, Peters V, Kohlschutter A, Hoffmann GF, Cantz M, Kopitz J: Towards quality assurance in the determination of lysosomal enzymes: a two-centre study. J Inherit Metab Dis 2003, 26:571-581.
13. Chamoles NA, Blanco M, Gaggioli D, Casentini C: Gaucher and NiemannPick diseases-enzymatic diagnosis in dried blood spots on filter paper: retrospective diagnoses in newborn-screening cards. Clin Chim Acta 2002, 317:191-197.

14. Chamoles NA, Blanco MB, lorcansky S, Gaggioli D, Specola N, Casentini C: Retrospective diagnosis of GM1 gangliosidosis by use of a newbornscreening card. Clin Chem 2001, 47:2068.

15. Chamoles NA, Blanco M, Gaggioli D: Fabry disease: enzymatic diagnosis in dried blood spots on filter paper. Clin Chim Acta 2001, 308:195-196.

16. Chamoles NA, Blanco M, Gaggioli D: Diagnosis of alpha-L-iduronidase deficiency in dried blood spots on filter paper: the possibility of newborn diagnosis. Clin Chem 2001, 47:780-781.

17. Chamoles NA, Niizawa G, Blanco M, Gaggioli D, Casentini C: Glycogen storage disease type II: enzymatic screening in dried blood spots on filter paper. Clin Chim Acta 2004, 347:97-102.

18. WHO: Hereditary Diseases Programme: guidelines for the development of national programmes for monitoring birth defects. 1993, 11-12, WHO/ HDP/ICBDMS/GL/93.4 (54 pp.).

19. Olivova P, van der Veen K, Cullen E, Rose M, Zhang XK, Sims KB, Keutzer J, Browning MF: Effect of sample collection on alpha-galactosidase A enzyme activity measurements in dried blood spots on filter paper. Clin Chim Acta 2009, 403:159-162.

20. De Jesus VR, Zhang XK, Keutzer J, Bodamer OA, Muhl A, Orsini JJ, Caggana M, Vogt RF, Hannon WH: Development and evaluation of quality control dried blood spot materials in newborn screening for lysosomal storage disorders. Clin Chem 2009, 55:158-164.

doi:10.1186/1746-1596-5-65

Cite this article as: Müller et al:: Reference values for lysosomal enzymes activities using dried blood spots samples - a Brazilian experience. Diagnostic Pathology 2010 5:65.

\section{Submit your next manuscript to BioMed Central and take full advantage of:}

- Convenient online submission

- Thorough peer review

- No space constraints or color figure charges

- Immediate publication on acceptance

- Inclusion in PubMed, CAS, Scopus and Google Scholar

- Research which is freely available for redistribution
C Biomed Central 